\title{
Effect of nano chelated nitrogen and urea fertilizers on wheat plant under drought stress condition
}

\author{
Naimeh ASTANEH ${ }^{1}$, Foroud BAZRAFSHAN ${ }^{1}$, Mahdi ZARE ${ }^{1 *}$, \\ Bahram AMIRI ${ }^{1}$, Abdollah BAHRINI ${ }^{2}$
}

\author{
${ }^{1}$ Department of Agriculture, Firoozabad Branch, Islamic Azad University, Firoozabad, Iran. \\ ${ }^{2}$ Department of Agriculture, Ramhormoz Branch, Islamic Azad University, Ramhormoz, Iran. \\ *E-mail: mahdi.zare2009@gmail.com
}

Recebido em junho/2018; Aceito em agosto/2018.

\begin{abstract}
This study was performed to evaluation of nano chelated nitrogen and urea fertilizers on wheat plant under drought stress condition. Experiments were carried out in two locations in Fars province, Iran. Experimental design was performed as split-split plot in RCBD design. The first factor included irrigation treatments (normal and withholding irrigation at flowering stage), sub factor was nitrogen treatment $(0,37,74$ and $\left.110 \mathrm{~kg} \cdot \mathrm{ha}^{-1}\right)$ in the form of Urea fertilizer, and sub-sub factor was nitrogen $\left(0,14,27\right.$ and $\left.41 \mathrm{~kg} \cdot \mathrm{ha}^{-1}\right)$ in the form of nano chelated nitrogen fertilizer. Studied traits included stem weight, spike weight, spike length, plant height, tiller number, stem diameter, anthocyanin, flavonoid, proline, soluble carbohydrates, chlorophyll a and b, carotenoid, 1000-seed weight, biological yield, seed yield and harvest index. According to analysis of variances, stress, nitrogen (urea) and nano chelated nitrogen had significant effects on all studied traits. According to mean comparisons, drought stress led to $51 \%$ reduction in seed yield compared to normal irrigation. Application of 37, 74 and $110 \mathrm{~kg} \mathrm{ha}^{-1}$ urea led to 9,19 and $27 \%$ increase in seed yield compared to control, respectively. Application of 14, 27 and $41 \mathrm{~kg} \cdot \mathrm{ha}^{-1}$ nano fertilizer led to 31, 44 and $98 \%$ increase in seed yield compared to control, respectively. In interaction between stress, urea and nano fertilizer on seed yield, was found that at normal and stress condition the highest mean of seed yield (7591 and $\left.4091 \mathrm{~kg} \cdot \mathrm{ha}^{-1}\right)$ was obtained by $110 \mathrm{~kg} \cdot \mathrm{ha}^{-1}$ urea and $41 \mathrm{~kg} \cdot \mathrm{ha}^{-1}$ nano fertilizer. In conclusion replacing urea by nano chelated nitrogen can increase the yield even in the drought stress and decrease amount of needed fertilizer.
\end{abstract}

Keywords: agronomic traits, biochemical traits, irrigation, seed yield.

\section{Efeito de nano-quelado de nitrogênio e ureia fertilizante em plantas de trigo sob condições de estresse hídrico}

RESUMO: Este estudo foi realizado para avaliar os efeitos de nitrogênio nano-quelatado e ureia fertilizante em plantas de trigo sob condição de estresse hídrico. Foram realizados experimentos em dois locais na província de Fars, no Irã. O delineamento experimental adotado foi em parcelas subdivididas no modelo RCBD. O primeiro fator incluiu os tratamentos de irrigação (irrigação normal e retenção na fase de floração), o subfator foi o tratamento com nitrogênio $\left(0,37,74\right.$ e $\left.110 \mathrm{~kg} \mathrm{ha}^{-1}\right)$ na forma de fertilizante ureia e sub-subfator foi nitrogênio $\left(0,14,27\right.$ e $\left.41 \mathrm{~kg} \mathrm{ha}^{-1}\right)$ na forma de adubo nitrogenado nano-quelatado. As características morfométricas estudadas foram o peso da haste, peso da espiga, comprimento da espiga, altura da planta, número do perfilho, diâmetro do caule, antocianina, flavonoides, prolina, carboidratos solúveis, clorofila aeb, carotenóides, peso de 1.000 sementes, rendimento biológico, produtividade e índice de colheita. De acordo com a análise de variâncias, o estresse hídrico, o nitrogênio (uréia) e o nitrogênio nano-quelatado apresentaram efeitos significativos em todas as características agronômicas estudadas. De acordo com comparações de médias, o estresse hídrico levou a uma redução de $51 \%$ no rendimento de sementes em comparação com a irrigação normal. A aplicação de 37, 74 e $110 \mathrm{~kg} \mathrm{ha}^{-1}$ de ureia levou a um aumento de 9, 19 e 27\% no rendimento de sementes em relação ao controle, respectivamente. A aplicação de 14, 27 e $41 \mathrm{~kg} \mathrm{ha}^{-1}$ de nano-quelatado levou a um aumento de 31, 44 e 98\% no rendimento de sementes em comparação com o controle, respectivamente. $\mathrm{Na}$ interação entre estresse, uréia e nano fertilizante na produtividade das sementes, verificou-se que nas condições normal e de estresse a maior média de produtividade de grãos (7591 e $4091 \mathrm{~kg} \mathrm{ha}^{-1}$ ) foi obtida em $110 \mathrm{~kg} \mathrm{ha}^{-1}$ de uréia e $41 \mathrm{~kg} \mathrm{ha}^{-1}$ adubo nano. Em conclusão, substituindo a ureia por nitrogênio nano-quelatado pode aumentar o rendimento, mesmo no estresse hídrico e diminuir a quantidade de fertilizante necessário.

Palavras-chave: características agronômicas, características bioquímicas, irrigação, produtividade de sementes.

\section{INTRODUCTION}

Wheat is one of the widely cultivated crops in Iran, where drought is the main limiting factor for its production. Drought is a major environmental stress threatening crops such as wheat productivity worldwide. Although drought impedes wheat performance at all growth stages, it is more critical during the flowering and grain-filling phases (terminal drought) and results in substantial yield losses (FAROOGH 
et al., 2014). The severity and duration of the stress determine the extent of the yield loss. The principal reasons for these losses are reduced rates of net photosynthesis owing to metabolic limitations (Ali et al., 2018) - oxidative damage to chloroplasts (Abid et al., 2018) and stomatal closure-and poor grain set and development (FAROOGH et al., 2014).

The response of plants to water stress depends on several factors such as development stage, severity and duration of stress and cultivar genetics (BELTRANO; MARTA, 2008). The adaptation strategies of the plants to drought stress include drought escape, drought avoidance and drought tolerance (LEVITT, 1980). Allahverdiyev et al. (2015) reported that drought caused reduction in photosynthesis rate, stomatal conductance, transpiration rate, mesophyll conductance, pigments content, area, dry weight, relative water content of flag leaves.

Efficient nitrogen nutrition has the potential to alleviate drought stress in crops by maintaining metabolic activities even at low tissue water potential. Wang et al. (2018) reported that nitrogen fertilization improved water-use efficiency of winter wheat through increasing water use during vegetative rather than grain filling. Wu et al. (2018) suggested that nutrient application has the potential to mitigate the drastic effects of water stress on Moso bamboo by improving photosynthetic rate, water-use efficiency, and increasing of membrane integrity.

In last decade, nanotechnology as a novel technology has solved many problems in different fields of science and industry and it has found its position and functions in agriculture. Nanotechnology has various functions in all stages from production, processing, storage, packing and transportation of agricultural products (SCOTT; CHEN, 2003). Nanofertilizers are the most important part of nanotechnology in the production phase of agriculture. Application of nanofertilizers instead of common fertilizers, nutrients are provided to plants gradually and in a controlled manner.

In relation to environmental effects, the nanotechnology increases the application efficiency of fertilizers, reduces soil pollution and environmental risks of chemical fertilizers (NADERI et al., 2011). In the previous study, Zareabyaneh; Bayatvarkeshi et al. (2015) showed that using nano chelated nitrogen could increase potato yield in comparison to urea. In the present study we compared the effects of nano chelated nitrogen, which is synthetized based on novel Nanochelating technology, with urea and the aim of this study was to investigate whether nutrition supply in the form of a nano structure can improve the drought tolerance of wheat under dry conditions.

\section{MATERIALS AND METHODS}

Experiments were carried out in two locations including Khodayan $\left(52^{\circ} 20^{\prime} \mathrm{E}, 29^{\circ} 8^{\prime} \mathrm{N}\right)$ and Nasrabad $\left(52^{\circ} 64^{\prime} \mathrm{E}\right.$ and $\left.29^{\circ} 58^{\prime} \mathrm{N}\right)$, Fars province, Iran. Table 1 shows some physicochemical properties of the soil at 0 to $30 \mathrm{~cm}$.

\subsection{Experimental design and treatments}

Experimental design was performed as split-split plot in RCBD design. The first factor included irrigation treatments (normal and withholding irrigation at flowering stage), sub factor was nitrogen treatment $\left(0,37,74\right.$ and $\left.110 \mathrm{~kg} \mathrm{ha}^{-1}\right)$ in the form of urea, and sub-sub factor was nitrogen $(0,14,27$ and $\left.41 \mathrm{~kg} \mathrm{ha}^{-1}\right)$ in the form of nano chelated nitrogen. The doses of urea and nano chelated nitrogen fertilizer were 80 , 160 and $240 \mathrm{~kg} \mathrm{ha}^{-1}$, which above mentioned doses are the doses of nitrogen element in the fertilizers that calculated based on this data: Urea has $46 \%$ nitrogen and nano nitrogen chelated fertilizer contained $17 \%$ nitrogen. Nano chelated nitrogen (Khazra) is produced by Sodour Ahrar Shargh Company, Tehran, Iran. It is synthetized based on novel Nanochelating technology, which is patented in USPTO (NAZARAN, 2012).

Table 1. Some physicochemical properties of the soil at 0 to $30 \mathrm{~cm}$. Tabela 1. Propriedades físico-químicas do solo de 0 a $30 \mathrm{~cm}$.

\begin{tabular}{|c|c|c|c|c|c|}
\hline & Khodayan & Nasrabad & $\mathrm{Kh}$ & yyan & Nasrabad \\
\hline $\begin{array}{l}\mathrm{Ec} \\
(\mathrm{dS} / \mathrm{m})\end{array}$ & 1.2 & 1.3 & $\begin{array}{l}\mathrm{Mn} \\
(\mathrm{ppm})\end{array}$ & 4 & 3.7 \\
\hline $\mathrm{pH}$ & 7.6 & 7.4 & $\mathrm{Fe}(\mathrm{ppm})$ & 7.5 & 7.7 \\
\hline $\mathrm{OM} \%$ & 2.4 & 2.2 & Clay $\%$ & 34.86 & 36.75 \\
\hline $\mathrm{C}$ & 1.65 & 1.63 & Silt \% & 47.23 & 47.55 \\
\hline $\mathrm{P}(\mathrm{ppm})$ & 13 & 15 & Sand $\%$ & 17.9 & 15.7 \\
\hline $\begin{array}{l}\text { K } \\
\text { (ppm) }\end{array}$ & 370 & 380 & $\mathrm{~N}(\mathrm{~kg} / \mathrm{ha})$ & 18.6 & 21.21 \\
\hline
\end{tabular}

\subsection{Field operations}

The field was as fallow in the last year. Field operation was done according to usual of region methods (plow, disc, land leveling and furrow). Fertilizer levels were determined after soil analysis (Table 1). Each plot contained 6 rows with 4 meters length and $0.2 \mathrm{~m}$ distance, with a constant density of 450 plants per square meter. In stem extension stage of wheat, weeds chemical control were carried out using Granstar herbicide (for the control of grassy weeds) and Puma super (for broadleaf weeds).

Final harvest was carried out at about 14\%moisture content. At the end of the growth period, some properties measured such as stem weight, spike weight, spike length, plant height, tiller number, stem diameter, Anthocyanin, flavonoid, proline, soluble carbohydrates, Chlorophyll a and b, carotenoid, 1000 seed weight, biological yield, seed yield.

Chlorophyll Content Assay - Leaf samples (1.0 g) were extracted in $10 \mathrm{~mL} 100 \%$ acetone using a mortar and pestle. The homogenate was filtered and centrifuged at $2000 \mathrm{rpm}$ for $2 \mathrm{~min}$. A $1 \mathrm{~mL}$ aliquot of the supernatant was pipetted and mixed with $9 \mathrm{~mL}$ of $80 \%$ acetone. The absorbance of the diluted samples was obtained using a spectrophotometer at 663 and $646 \mathrm{~nm}$ (IANCULOV et al., 2005):

Total Soluble Carbohydrate Assay - Soluble carbohydrate was estimated according to the method proposed by Dubois et al. (1956). Leaf samples were homogenized in a mortar and pestle with $3 \mathrm{~mL}$ distilled water and the homogenate was filtered using a filter paper. Phenol $(0.5 \mathrm{~mL}, 5 \%)$ and $2.5 \mathrm{~mL}$ of $98 \%$ sulfuric acid were added to the homogenate. After the reaction of the materials, the test tubes were allowed to cool to room temperature. The carbohydrate content was determined from the absorbance measured at $483 \mathrm{~nm}$ and calculated based on a standard curve.

\subsection{Data analysis}

Data were analyzed using the general linear model (GLM) procedure of the statistical analysis system, SAS software. When analysis of variance showed significant treatment effects, Duncan's multiple range tests were applied to compare the means at $\mathrm{P}<0.05$. 


\section{RESULTS AND DISCUSSION}

\subsection{Stem and spike weight}

According to analysis of variances it was found that all treatments and their interaction had significant effects on stem weight at $1 \%$ or $5 \%$ statistically levels. Also spike weight affected by stress*urea*Nano interaction at $1 \%$ statistically level. Liu et al. (2016) mentioned that mild stress during all of the growth stages improved the distribution of assimilate to the grain prior to anthesis and increased the yield. Although moderate stress during all growth stages could improve dry matter translocation, the resulting yield was not high, as the accumulation of dry matter decreased after anthesis. Therefore, mild soil water stress can improve grain yields and WUE.

According to mean comparisons, drought stress led to 26 and $31 \%$ reduction in stem and spike weight compared to normal irrigation, respectively. Application of 37, 74 and 110 $\mathrm{kg} \mathrm{ha}^{-1}$ urea led to 5, 9 and $3 \%$ increase in stem weight and 15,15 and $8 \%$ increase in spike weight compared to control, respectively. Application of 14,27 and $41 \mathrm{~kg} \mathrm{ha}^{-1}$ nano fertilizer led to 16,37 and $52 \%$ increase in stem weight and 12,40 and $56 \%$ increase in spike weight compared to control, respectively. In relation to interaction between stress, urea and nano fertilizer on stem weight, it was found that at normal condition the highest mean of stem weight $(1.37 \mathrm{~kg}$ $\mathrm{m}^{-2}$ ) was obtained by $110 \mathrm{~kg} \mathrm{ha}^{-1}$ urea and $41 \mathrm{~kg} \mathrm{ha}^{-1}$ nano fertilizer, at stress condition the highest mean $\left(1.05 \mathrm{kgm}^{-2}\right)$ obtained by $110 \mathrm{~kg} \mathrm{ha}^{-1}$ urea and $27 \mathrm{~kg} \mathrm{ha}^{-1}$ nano fertilizer. In relation to interaction between stress, urea and nano fertilizer on spike weight, it was found that at normal condition the highest mean of spike weight $\left(1.14 \mathrm{~kg} \mathrm{~m}^{-2}\right)$ was obtained by $110 \mathrm{~kg} \mathrm{ha}^{-1}$ urea and $41 \mathrm{~kg} \mathrm{ha}^{-1}$ nano fertilizer, at stress condition the highest mean $\left(0.83 \mathrm{~kg} \mathrm{~m}^{-2}\right)$ obtained by 110 $\mathrm{kgha}^{-1}$ urea and $27 \mathrm{~kg} \mathrm{ha}^{-1}$ nano fertilizer.

Anjum et al. (2011) reported that drought stress disrupts photosynthetic pigments and reduces the gas exchange leading to a reduction in plant growth and productivity.

Table 2. Analysis of variances for studied traits.

Tabela 2. Análise de variâncias para características agronômicas estudadas.

\begin{tabular}{|c|c|c|c|c|c|c|c|c|c|c|}
\hline & & $\begin{array}{c}\text { Stem } \\
\text { weight }\end{array}$ & $\begin{array}{l}\text { Spike } \\
\text { weight }\end{array}$ & $\begin{array}{l}\text { Spike } \\
\text { length }\end{array}$ & $\begin{array}{l}\text { Plant } \\
\text { height }\end{array}$ & $\begin{array}{c}\text { Tiller } \\
\text { number }\end{array}$ & $\begin{array}{c}\text { Stem } \\
\text { diameter }\end{array}$ & Anthocyanin & Flavonoid & Proline \\
\hline Location & 1 & $15.956^{* *}$ & $0.263 * *$ & $99.188 * *$ & $33.911 * *$ & $916597 * *$ & $4.533 * *$ & $0.707 * *$ & 0.0001 & $30.944 * *$ \\
\hline Error & 4 & $0.014 *$ & 0.0001 & $4.656 * *$ & $0.072 * *$ & $707.2 * *$ & $0.104 * *$ & $0.047 * *$ & $0.051 * *$ & $0.275^{* *}$ \\
\hline Drought Stress & 1 & $3.783 * *$ & $0.071 * *$ & $108^{* *}$ & $8.589 * *$ & $519792 * *$ & $1.188 * *$ & $0.487 * *$ & $0.325 * *$ & $88.835 * *$ \\
\hline Location* Drought stress & 1 & $0.027 *$ & 0.0001 & $13.021 * *$ & $0.128 * *$ & $3185 * *$ & $0.033 *$ & $0.024 * *$ & $0.05^{* *}$ & $0.725 * *$ \\
\hline Error & 4 & $0.016 * *$ & 0.0001 & 0.104 & 0.001 & 32.83 & 0.016 & 0.003 & 0.005 & 0.027 \\
\hline Urea & 3 & $0.057 * *$ & $0.002 * *$ & $75.181 * *$ & $0.299 * *$ & $33560 * *$ & $2.384 * *$ & $0.698 * *$ & $0.766 * *$ & $2.801 * *$ \\
\hline Location*Urea & 3 & $0.051 * *$ & $0.001 * *$ & 0.285 & $1.339 * *$ & $4902 * *$ & $0.416 * *$ & $0.01 *$ & 0.009 & 0.064 \\
\hline Drought Stress*Urea & 3 & $0.059 * *$ & $0.000333 * *$ & 0.236 & $0.29 * *$ & $1103 * *$ & 0.014 & 0.002 & $0.032 * *$ & $0.225 * *$ \\
\hline Location*Stress*Urea & 3 & $0.12 * *$ & $0.000333^{* *}$ & 0.118 & $0.233^{* *}$ & $3617 * *$ & 0.022 & 0.001 & 0.01 & 0.029 \\
\hline Error & 24 & 0.004 & 8.33E-05 & 0.283 & 0.003 & 12.71 & 0.008 & 0.003 & 0.004 & 0.046 \\
\hline Nano & 3 & $1.335 * *$ & $0.021 * *$ & $154.097 * *$ & $4.859 * *$ & $42029 * *$ & $5.026 * *$ & $1.951 * *$ & $1.897 * *$ & $5.276 * *$ \\
\hline Location*Nano & 3 & $0.192 * *$ & $0.003 * *$ & 0.035 & $0.525 * *$ & $112.5 * *$ & $0.293 * *$ & $0.014 * *$ & 0.002 & $0.121 *$ \\
\hline Drought Stress*Nano & 3 & $0.123 * *$ & $0.001 * *$ & 0.208 & $0.222 * *$ & $2994 * *$ & $0.04 * *$ & 0.004 & $0.018 * *$ & $0.14^{*}$ \\
\hline Location*Stress*Nano & 3 & $0.024 *$ & $0.002 * *$ & 0.368 & $0.391 * *$ & $149.0 * *$ & $0.041 * *$ & 0.006 & $0.013^{*}$ & 0.048 \\
\hline Urea*Nano & 9 & $0.07 * *$ & $0.001 * *$ & $0.722 * *$ & $0.259 * *$ & $1917 * *$ & $0.366^{* *}$ & $0.027 * *$ & $0.024 * *$ & $0.232 * *$ \\
\hline Location*Urea*Nano & 9 & $0.03 * *$ & $0.000333^{* *}$ & 0.095 & $0.258 * *$ & $2331 * *$ & $0.168 * *$ & $0.007 *$ & 0.006 & $0.091 *$ \\
\hline Drought Stress*Urea*nano & 9 & $0.025 * *$ & 0.000444 & 0.296 & $0.284 * *$ & $895.5 * *$ & $0.01 *$ & 0.001 & $0.021 * *$ & 0.073 \\
\hline $\begin{array}{l}\text { Location* Drought } \\
\text { Stress*Urea*Nano }\end{array}$ & 9 & $0.059 * *$ & $0.001 * *$ & 0.169 & $0.127 * *$ & $2343 * *$ & $0.018 * *$ & $0.006^{*}$ & $0.008^{*}$ & 0.055 \\
\hline Error & 96 & 0.006 & $3.13 \mathrm{E}-05$ & 0.259 & 0.001 & 14.656 & 0.005 & 0.003 & 0.004 & 0.046 \\
\hline
\end{tabular}

\subsection{Spike length and plant height}

According to Table 2, drought stress, urea and nano treatments showed significant effects on spike length at $1 \%$ statistically level and all simple effects and their interaction had significant effects on plant height at $1 \%$ statistically level. According to mean comparisons, drought stress led to 14 and $10 \%$ reduction in spike length and plant height compared to normal irrigation, respectively. Application of 37,74 and $110 \mathrm{~kg} \mathrm{ha}^{-1}$ urea led to 14,16 and $38 \%$ increase in spike length and 5, 1 and 3\% increase in plant height compared to control, respectively. Application of 14, 27 and $41 \mathrm{~kg} \mathrm{ha}^{-1}$ nano fertilizer led to 29,43 and $61 \%$ increase in spike length and 10, 11 and $22 \%$ increase in plant height compared to control, respectively.

In relation to interaction between drought stress, urea and nano fertilizer on spike length, it was found that at normal and stress condition the highest mean of spike length (13.33 and $12.17 \mathrm{~cm}$, respectively) were obtained by $110 \mathrm{~kg} \mathrm{ha}^{-1}$ urea and $41 \mathrm{~kg} \mathrm{ha}^{-1}$ nano fertilizer. In relation to interaction between drought stress, urea and nano fertilizer on plant height, it was found that at normal and stress condition the highest mean of plant height $(70.5$ and $60.02 \mathrm{~cm})$ were obtained by $110 \mathrm{~kg} \mathrm{ha}^{-1}$ urea and $41 \mathrm{~kg} \mathrm{ha}^{-1}$ nano fertilizer.

\subsection{Tiller number and stem diameter}

Tiller number affected by all simple effects and their interaction at $1 \%$ statistically level, in relation to stem diameter simple effects had significant effects at $1 \%$ statistically level, also location*urea*nano had significant effects at 5\% statistically level on stem diameter. According to mean comparisons, drought stress led to 27 and $6 \%$ reduction in tiller number and stem diameter compared to normal irrigation, respectively. Application of 37, 74 and 110 $\mathrm{kg} \mathrm{ha}^{-1}$ urea led to 6,11 and $21 \%$ increase in tiller number and 12,12 and $24 \%$ increase in stem diameter compared to control, respectively. Application of 14, 27 and $41 \mathrm{~kg} \mathrm{ha}^{-1}$ nano fertilizer led to 8,15 and $23 \%$ increase in tiller number and 23, 27 and 36\% increase in stem diameter compared to control, respectively. In relation to interaction between stress, urea and nano fertilizer on tiller number, it was found that at normal condition the highest mean of tiller number (448 per $\mathrm{m}^{2}$ ) was obtained by $110 \mathrm{~kg} \mathrm{ha}^{-1}$ urea and 41 per $\mathrm{m}^{2}$ nano fertilizer, at stress condition the highest mean $\left(342\right.$ per $\left.\mathrm{m}^{2}\right)$ obtained by $74 \mathrm{~kg} \mathrm{ha}^{-1}$ urea and $41 \mathrm{~kg} \mathrm{ha}^{-1}$ nano fertilizer. In relation to interaction between drought stress, urea and nano fertilizer on stem diameter, it was found that at normal and 
stress condition the highest mean of stem diameter ( 3 and 2.85 per $\mathrm{m}^{2}$ respectively) were obtained by $74 \mathrm{~kg} \mathrm{ha}^{-1}$ urea and $41 \mathrm{~kg} \mathrm{ha}^{-1}$ nano fertilizer.

\subsection{Anthocyanin and flavonoid}

These traits affected by drought stress, urea and nano fertilizer at $1 \%$ statistically level. According to mean comparisons, drought stress led to 9 and $5 \%$ increase in anthocyanin and flavonoid compared to normal irrigation, respectively. Application of 37,74 and $110 \mathrm{~kg} \mathrm{ha}^{-1}$ urea led to 10, 20 and $27 \%$ increase in anthocyanin and 8, 13 and $22 \%$ increase in flavonoid compared to control, respectively.
Application of 14, 27 and $41 \mathrm{~kg} \mathrm{ha}^{-1}$ nano fertilizer led to 21, 35 and $51 \%$ increase in anthocyanin and 12, 24 and $35 \%$ increase in flavonoid by the compared to control, respectively. In relation to interaction between stress, urea and nano fertilizer on anthocyanin, it was found that at normal and stress condition the highest mean of anthocyanin (1.5 and 1.6 respectively) were obtained by $110 \mathrm{~kg} \mathrm{ha}^{-1}$ urea and $41 \mathrm{~kg} \mathrm{ha}^{-1}$ nano fertilizer. In relation to interaction between stress, urea and nano fertilizer on flavonoid, it was found that at normal and stress condition the highest mean of flavonoid (1.85 and 1.98 respectively) was obtained by 110 $\mathrm{kg} \mathrm{ha}^{-1}$ urea and $41 \mathrm{~kg} \mathrm{ha}^{-1}$ nano fertilizer.

Table 3. Means comparison between interaction of treatments on studied traits.

Tabela 3. Comparação entre as interações das características agronômicas avaliadas.

\begin{tabular}{|c|c|c|c|c|c|c|c|c|c|c|c|c|c|c|}
\hline & $\begin{array}{c}\text { Urea } \\
(\mathrm{kg} / \mathrm{ha})\end{array}$ & $\begin{array}{c}\text { Nano } \\
(\mathrm{kg} / \mathrm{ha})\end{array}$ & $\begin{array}{l}\text { Stem weight } \\
\left(\mathrm{kg} \cdot \mathrm{m}^{-2}\right)\end{array}$ & & $\begin{array}{l}\text { Spike weight } \\
\left(\mathrm{kg} \cdot \mathrm{m}^{-2}\right)\end{array}$ & & $\begin{array}{l}\text { Spike length } \\
\quad(\mathrm{cm})\end{array}$ & & $\begin{array}{l}\text { Plant height } \\
\text { (cm) }\end{array}$ & & $\begin{array}{l}\text { Tiller } \\
\text { number }\end{array}$ & & $\begin{array}{c}\text { Stem } \\
\text { diameter } \\
(\mathrm{mm})\end{array}$ & \\
\hline \multirow{16}{*}{ Normal } & 0 & 0 & 0.6667 & $\mathrm{jk}$ & 0.517 & $q$ & 6.333 & $q$ & 50.89 & $q$ & 306 & $\mathrm{p}$ & 1.533 & $\mathrm{n}$ \\
\hline & & 14 & 0.8333 & efgh & 0.733 & $\mathrm{j}$ & 8.5 & $\mathrm{klm}$ & 57.90 & $\mathrm{j}$ & 351.7 & $\mathrm{k}$ & 2.45 & $\mathrm{j}$ \\
\hline & & 27 & 1.05 & c & 0.850 & $\mathrm{f}$ & 9.333 & hij & 59.27 & 1 & 370 & $\mathrm{i}$ & 2.583 & hi \\
\hline & & 41 & 1.317 & $\mathrm{a}$ & 0.983 & $\mathrm{c}$ & 10.33 & efg & 64.30 & $\mathrm{c}$ & 404.2 & $\mathrm{~d}$ & 2.85 & $\mathrm{c}$ \\
\hline & 37 & 0 & 0.9 & & 0.833 & $\mathrm{gh}$ & 7.5 & op & 55.13 & $\mathrm{mn}$ & 321.5 & $\mathrm{n}$ & 2.133 & $\operatorname{lm}$ \\
\hline & & 14 & 1.033 & $\mathrm{c}$ & 0.783 & gh & 9.5 & hi & 61.50 & $\mathrm{e}$ & 361 & $\mathrm{j}$ & 2.717 & efg \\
\hline & & 27 & 1.15 & b & 0.933 & e & 10.33 & efg & 63.50 & $\mathrm{~d}$ & 396.3 & $\mathrm{e}$ & 2.75 & def \\
\hline & & 41 & 1.317 & $\mathrm{a}$ & 1.100 & $\mathrm{~b}$ & 11.5 & $\mathrm{c}$ & 67.00 & b & 415.8 & $\mathrm{c}$ & 3.017 & $\mathrm{a}$ \\
\hline & 74 & 0 & 0.7667 & fghij & 0.683 & 1 & 7.667 & no & 54.40 & o & 332 & $\mathrm{~m}$ & 2.25 & $\mathrm{k}$ \\
\hline & & 14 & 1.017 & $\mathrm{c}$ & 0.783 & $\mathrm{gh}$ & 9.333 & hij & 60.50 & $\mathrm{f}$ & 375 & $\mathrm{~h}$ & 2.633 & ghi \\
\hline & & 27 & 1.2 & b & 0.900 & $\mathrm{de}$ & 10.67 & ef & 63.57 & d & 391.7 & $\mathrm{f}$ & 2.7 & fg \\
\hline & & 41 & 1.375 & $\mathrm{a}$ & 1.142 & $\mathrm{a}$ & 12.33 & b & 67.10 & b & 424.5 & $\mathrm{~b}$ & 3.033 & $\mathrm{a}$ \\
\hline & 110 & 0 & 0.9167 & de & 0.800 & $\mathrm{~g}$ & 9.333 & hij & 54.53 & 0 & 384.2 & $\mathrm{~g}$ & 2.717 & efg \\
\hline & & 14 & 0.8767 & $\mathrm{e}$ & 0.753 & $\hat{\mathrm{hi}}$ & 11.33 & $\mathrm{~cd}$ & 58.00 & $\mathrm{j}$ & 404.8 & $\mathrm{~d}$ & 2.933 & $\mathrm{~b}$ \\
\hline & & 27 & 1.15 & b & 0.950 & $\mathrm{~d}$ & 12.67 & $\mathrm{~b}$ & 60.50 & $\mathrm{fg}$ & 422 & $\mathrm{~b}$ & 3.067 & $\mathrm{a}$ \\
\hline & & 41 & 1.2 & b & 1.000 & b & 13.33 & a & 70.50 & $\mathrm{a}$ & 448 & $\mathrm{a}$ & 3.05 & $\mathrm{a}$ \\
\hline \multirow{16}{*}{ Stress } & 0 & 0 & 0.5667 & 1 & 0.350 & $\mathrm{t}$ & 4.833 & $\mathrm{r}$ & 46.83 & $\mathrm{~S}$ & 224 & W & 1.5 & $\mathrm{n}$ \\
\hline & & 14 & 0.7 & $\mathrm{jk}$ & 0.467 & $\mathrm{r}$ & 7 & $\mathrm{p}$ & 54.33 & 0 & 246 & $\mathrm{~V}$ & 2.4 & $\mathrm{j}$ \\
\hline & & 27 & 0.8167 & efghi & 0.667 & $1 \mathrm{~m}$ & 8.167 & $\mathrm{mn}$ & 56.00 & $\mathrm{k}$ & 262.8 & $\mathrm{u}$ & 2.4 & $\mathrm{j}$ \\
\hline & & 41 & 0.9833 & $\mathrm{~cd}$ & 0.717 & $\mathrm{k}$ & 8.833 & $\mathrm{jkl}$ & 59.67 & $\mathrm{gh}$ & 248.7 & $\mathrm{~V}$ & 2.65 & $\mathrm{gh}$ \\
\hline & 37 & 0 & 0.55 & 1 & 0.400 & $\mathrm{~S}$ & 6 & $q$ & 51.55 & $p$ & 214.8 & $x$ & 2.067 & $\mathrm{~m}$ \\
\hline & & 14 & 0.7667 & fghij & 0.617 & $\mathrm{n}$ & 8 & mno & 54.52 & no & 248.7 & $\mathrm{~V}$ & 2.467 & $\mathrm{j}$ \\
\hline & & 27 & 0.7333 & hijk & 0.650 & $\mathrm{mn}$ & 9 & ijk & 58.12 & $\mathrm{j}$ & 285.2 & $\mathrm{r}$ & 2.65 & gh \\
\hline & & 41 & 0.8667 & ef & 0.750 & ij & 10.17 & fg & 59.50 & hi & 305 & $\mathrm{p}$ & 2.817 & $\mathrm{~cd}$ \\
\hline & 74 & 0 & 0.6333 & $\mathrm{kl}$ & 0.467 & $\mathrm{r}$ & 5.833 & $\mathrm{q}$ & 51.25 & $\mathrm{pq}$ & 268 & $\mathrm{t}$ & 2.183 & $\mathrm{kl}$ \\
\hline & & 14 & 0.7083 & $\mathrm{jk}$ & 0.517 & $\mathrm{p}$ & 8.167 & $\mathrm{mn}$ & 55.30 & $\mathrm{~lm}$ & 267.5 & $\mathrm{t}$ & 2.45 & $\mathrm{j}$ \\
\hline & & 27 & 1.05 & c & 0.833 & $\mathrm{gh}$ & 8.333 & $\operatorname{lm}$ & 42.70 & $\mathrm{t}$ & 280.2 & $\mathrm{~s}$ & 2.55 & $\mathrm{i}$ \\
\hline & & 41 & 0.85 & efg & 0.750 & ij & 10.83 & de & 59.20 & 1 & 342 & 1 & 2.8 & cde \\
\hline & 110 & 0 & 0.7333 & hijk & 0.500 & $\mathrm{q}$ & 8 & mno & 49.83 & $\mathrm{r}$ & 312.8 & 0 & 2.583 & hi \\
\hline & & 14 & 0.7217 & ijk & 0.450 & $\mathrm{r}$ & 9.833 & gh & 51.97 & $\mathrm{p}$ & 296 & $\mathrm{q}$ & 2.75 & def \\
\hline & & 27 & 0.75 & ghij & 0.600 & 0 & 10.83 & de & 56.03 & $\mathrm{kl}$ & 312.5 & 0 & 2.783 & cdef \\
\hline & & 41 & 0.8467 & efg & 0.667 & $\mathrm{n}$ & 12.17 & $\mathrm{~b}$ & 60.02 & $\mathrm{gh}$ & 329.5 & $\mathrm{~m}$ & 2.85 & c \\
\hline
\end{tabular}

\subsection{Proline and soluble carbohydrates}

These traits affected by drought stress, urea and nano fertilizer at $1 \%$ statistically level. According to mean comparisons, drought stress led to 1.95 and 1.49 increase in proline and soluble carbohydrates compared to normal irrigation, respectively. The results of Keyvan (2010) showed that with an increase in the intensity of drought stress on wheat cultivars, there was a decrease in relative water content, total chlorophyll content and increased proline content, but was not observed on trend relating to soluble carbohydrates content. $\mathrm{Xu}$ et al. (2015) reported that drought stress condition significantly increased leaf sucrosephosphate synthase.

Application of 37,74 and $110 \mathrm{~kg} \mathrm{ha}^{-1}$ urea led to 14,14 and $31 \%$ increase in proline, also 74 and $110 \mathrm{kgha}^{-1}$ urea led to 8 and $23 \%$ increase in soluble carbohydrates compared to control, respectively. Application of 14, 27 and $41 \mathrm{~kg} \mathrm{ha}^{-1}$ nano fertilizer led to 14,24 and $44 \%$ the increase in proline and 17, 24 and 34\% increase in soluble carbohydrates compared to control, respectively.
In relation to interaction between drought stress, urea and nano fertilizer on proline, it was found that at normal and stress condition the highest mean of proline (15.65 and 31.5, respectively) were obtained by $110 \mathrm{~kg} \mathrm{ha}^{-1}$ urea and $41 \mathrm{~kg}$ ha ${ }^{1}$ nano fertilizer. In relation to interaction between stress, urea and nano fertilizer on soluble carbohydrates, it was found that at normal and stress condition the highest mean of soluble carbohydrates ( 2.05 and 2.88 , respectively) were obtained by $110 \mathrm{~kg} \mathrm{ha}^{-1}$ urea and $41 \mathrm{~kg} \mathrm{ha}^{-1}$ nano fertilizer.

\subsection{Chlorophyll a and $\mathrm{b}$}

Chlorophyll $\mathrm{a}$ and $\mathrm{b}$ affected by drought stress, urea and nano fertilizer at $1 \%$ statistically level, according to mean comparisons, drought stress led to 16 and $11 \%$ reduction in chlorophyll $\mathrm{a}$ and $\mathrm{b}$ compared to normal irrigation, respectively. Water deficit can destroy chlorophyll and prevent making it (Lessani; Mojtahedi, 2002). Also, some researchers have reported damage to leaf pigments as a result of water deficit (Arjenaki, 20102). Mensah et al. (2006) found that subjecting sesame to drought stress caused leaf chlorophyll was increased and then remained unchanged. 
Application of 37,74 and $110 \mathrm{~kg} \mathrm{ha}^{-1}$ urea led to 1,12 and $31 \%$ increase in chlorophyll a and 7, 11 and 34\% increase in chlorophyll b compared to control, respectively. Application of 14, 27 and $41 \mathrm{~kg} \mathrm{ha}^{-1}$ nano fertilizer led to 32, 55 and $96 \%$ increase in chlorophyll a and 37, 54 and 96\% increase in chlorophyll b compared to control, respectively.

In relation to interaction between drought stress, urea and nano fertilizer on chlorophyll $\mathrm{a}$, it was found that at normal and stress condition the highest mean of chlorophyll a $(2.51$ and 2.11 , respectively) were obtained by $110 \mathrm{~kg} \mathrm{ha}^{-1}$ urea and $41 \mathrm{~kg} \mathrm{ha}^{-1}$ nano fertilizer. In relation to interaction between drought stress, urea and nano fertilizer on chlorophyll $b$, it was found that at normal and stress condition the highest mean of chlorophyll b ( 1 and 082 , respectively) were obtained by $110 \mathrm{~kg} \mathrm{ha}^{-1}$ urea and $41 \mathrm{~kg} \mathrm{ha}^{-1}$ nano fertilizer.

Table 3. Means comparison between interaction of treatments on studied traits. (continuing...)

Tabela 3. Comparação entre as interações das características agronômicas avaliadas. (continuação...)

\begin{tabular}{|c|c|c|c|c|c|c|c|c|c|c|c|c|c|c|}
\hline & $\begin{array}{c}\text { Urea } \\
(\mathrm{kg} / \mathrm{ha})\end{array}$ & $\begin{array}{c}\text { Nano } \\
(\mathrm{kg} / \mathrm{ha})\end{array}$ & Antho & & Flavo & & Pro & & $\begin{array}{r}\text { So } \\
\text { carbo } \\
\end{array}$ & $\begin{array}{l}\text { de } \\
\text { drates }\end{array}$ & Chlor & & $\mathrm{Chl}$ & phyll \\
\hline \multirow{16}{*}{ Normal } & 0 & 0 & 0.76 & $\mathrm{~m}$ & 1.1 & $\mathrm{p}$ & 7.05 & o & 0.85 & $\mathrm{n}$ & 0.892 & S & 0.365 & $\mathrm{p}$ \\
\hline & & 14 & 0.93 & $\mathrm{jk}$ & 1.317 & $\mathrm{n}$ & 10.47 & $\mathrm{mn}$ & 1.27 & klm & 1.563 & $\operatorname{lm}$ & 0.5917 & $\mathrm{j}-\mathrm{m}$ \\
\hline & & 27 & 1.05 & gh & 1.417 & $\operatorname{lm}$ & 11.58 & $\mathrm{klm}$ & 1.5 & g-k & 1.823 & $\mathrm{j}$ & 0.675 & g-j \\
\hline & & 41 & 1.1 & $\mathrm{f}$ & 1.583 & fgh & 13.55 & hij & 1.633 & $g-j$ & 2.250 & $\mathrm{~cd}$ & 0.845 & $\mathrm{c}$ \\
\hline & 37 & 0 & 0.87 & 1 & 1.167 & op & 10.78 & $\operatorname{lmn}$ & 1.2 & $\operatorname{lm}$ & 1.072 & $q$ & 0.42 & op \\
\hline & & 14 & 0.98 & ij & 1.3 & $\mathrm{n}$ & 11.20 & klm & 1.45 & h-l & 1.202 & $\mathrm{p}$ & 0.5017 & mno \\
\hline & & 27 & 1.1 & fg & 1.55 & hij & 11.37 & klm & 1.567 & $g-j$ & 1.883 & ij & 0.71 & $f-i$ \\
\hline & & 41 & 1.3 & $\mathrm{~d}$ & 1.7 & de & 13.50 & ij & 1.7 & ghi & 2.450 & $\mathrm{~b}$ & 0.9417 & $a b$ \\
\hline & 74 & 0 & 0.88 & $\mathrm{kl}$ & 1.2 & 0 & 9.32 & $\mathrm{n}$ & 1.083 & $\mathrm{mn}$ & 1.187 & $p$ & 0.425 & op \\
\hline & & 14 & 1.16 & $\mathrm{f}$ & 1.567 & ghi & 10.90 & k-n & 1.383 & $\mathrm{jkl}$ & 1.687 & $\mathrm{k}$ & 0.6333 & h-1 \\
\hline & & 27 & 1.26 & $\mathrm{e}$ & 1.667 & def & 12.48 & $\mathrm{jkl}$ & 1.608 & g-j & 1.900 & hi & 0.59 & $j-m$ \\
\hline & & 41 & 1.41 & $\mathrm{c}$ & 1.8 & $\mathrm{bc}$ & 14.35 & hij & 1.717 & gh & 2.300 & $\mathrm{c}$ & 0.8667 & $\mathrm{bc}$ \\
\hline & 110 & 0 & 1.013 & hi & 1.483 & $\mathrm{jkl}$ & 11.60 & $\mathrm{klm}$ & 1.4 & ijkl & 1.767 & ij & 0.6833 & $g-i$ \\
\hline & & 14 & 1.15 & $\mathrm{f}$ & 1.6 & fgh & 12.90 & $\mathrm{jk}$ & 1.517 & g-k & 1.900 & gh & 0.7167 & $e-i$ \\
\hline & & 27 & 1.33 & $\mathrm{~d}$ & 1.667 & def & 14.03 & hij & 1.8 & fg & 2.083 & ef & 0.805 & cdef \\
\hline & & 41 & 1.5 & $\mathrm{~b}$ & 1.85 & $\mathrm{~b}$ & 15.65 & $\mathrm{~h}$ & 2.05 & ef & 2.517 & $\mathrm{a}$ & 1.002 & $\mathrm{a}$ \\
\hline \multirow{16}{*}{ Stress } & 0 & 0 & 0.83 & 1 & 1.133 & op & 15.13 & hi & 1.483 & h-1 & 0.667 & $\mathrm{t}$ & 0.265 & $\mathrm{q}$ \\
\hline & & 14 & 1.06 & gh & 1.35 & $\mathrm{mn}$ & 17.16 & $\mathrm{~h}$ & 2.183 & de & 1.267 & $\mathrm{p}$ & 0.49 & no \\
\hline & & 27 & 1.16 & $\mathrm{f}$ & 1.583 & fgh & 21.65 & $\mathrm{f}$ & 2.4 & bcd & 1.470 & $\mathrm{~m}$ & 0.555 & $\operatorname{lmn}$ \\
\hline & & 41 & 1.23 & $\mathrm{e}$ & 1.65 & efg & 26.28 & $\mathrm{bc}$ & 2.417 & bcd & 1.817 & ij & 0.705 & $\mathrm{f}-\mathrm{i}$ \\
\hline & 37 & 0 & 0.96 & iij & 1.45 & $\mathrm{kl}$ & 20.83 & $\mathrm{f}$ & 2.133 & $\mathrm{de}$ & 0.883 & $\mathrm{~s}$ & 0.3617 & $p$ \\
\hline & & 14 & 1.1 & $\mathrm{fg}$ & 1.467 & $\mathrm{kl}$ & 22.87 & def & 2.25 & cde & 1.017 & $q$ & 0.4333 & op \\
\hline & & 27 & 1.25 & $\mathrm{e}$ & 1.65 & efg & 22.80 & def & 1.617 & ghij & 1.333 & 0 & 0.62 & i-1 \\
\hline & & 41 & 1.43 & $\mathrm{c}$ & 1.733 & $\mathrm{~cd}$ & 26.22 & $\mathrm{bc}$ & 1.717 & $\mathrm{gh}$ & 2.067 & $\mathrm{f}$ & 0.8133 & cde \\
\hline & 74 & 0 & 0.94 & ijk & 1.35 & $\mathrm{mn}$ & 18.52 & $\mathrm{~g}$ & 2.017 & ef & 0.953 & $\mathrm{r}$ & 0.3717 & $\mathrm{p}$ \\
\hline & & 14 & 1.26 & $\mathrm{e}$ & 1.5 & ijk & 22.18 & ef & 2.167 & de & 1.495 & $\mathrm{n}$ & 0.6633 & g-k \\
\hline & & 27 & 1.35 & $\mathrm{~d}$ & 1.633 & efg & 24.72 & cde & 2.35 & $\mathrm{~cd}$ & 1.623 & 1 & 0.6467 & h-1 \\
\hline & & 41 & 1.5 & $\mathrm{~b}$ & 1.833 & $\mathrm{~b}$ & 27.73 & $\mathrm{~b}$ & 2.517 & $\mathrm{bc}$ & 2.000 & $\mathrm{~g}$ & 0.7667 & $\mathrm{c}-\mathrm{g}$ \\
\hline & 110 & 0 & 1.1 & $\mathrm{fg}$ & 1.55 & hii & 23.58 & def & 2.267 & cde & 1.532 & $\mathrm{~lm}$ & 0.5683 & k-n \\
\hline & & 14 & 1.2 & $\mathrm{e}$ & 1.633 & efg & 25.37 & bcd & 2.35 & $\mathrm{~cd}$ & 1.665 & $\mathrm{k}$ & 0.6967 & ghi \\
\hline & & 27 & 1.46 & bc & 1.783 & $\mathrm{bc}$ & 26.77 & bc & 2.633 & $a b$ & 1.767 & ij & 0.7283 & d-h \\
\hline & & 41 & 1.6 & $\mathrm{a}$ & 1.983 & $\mathrm{a}$ & 31.50 & $\mathrm{a}$ & 2.883 & $\mathrm{a}$ & 2.117 & de & 0.825 & $\mathrm{~cd}$ \\
\hline
\end{tabular}

\subsection{Carotenoid}

This trait affected by drought stress, urea and nano fertilizer at 5\% statistically level, according to mean comparisons, drought stress led to $10 \%$ the reduction in carotenoid by the compared to normal irrigation, respectively. Application of 37, 74 and $110 \mathrm{~kg} \mathrm{ha}^{-1}$ urea led to 16,5 and $54 \%$ increase in carotenoid and application of 14 , 27 and $41 \mathrm{~kg} \mathrm{ha}^{-1}$ nano fertilizer led to 26,42 and $62 \%$ increase in carotenoid. In relation to interaction between stress, urea and nano fertilizer on carotenoid, it was found that at normal and stress condition the highest mean of carotenoid (2.25 and 1.86, respectively) were obtained by $110 \mathrm{~kg} \mathrm{ha}^{-1}$ urea and $41 \mathrm{~kg} \mathrm{ha}^{-1}$ nano fertilizer.

\subsection{0-seed weight and seed yield}

These traits affected by stress, urea and nano fertilizer at $1 \%$ statistically level. According to mean comparisons, drought stress led to 7 and $51 \%$ reduction in 1000 -seed weight and seed yield compared to normal irrigation, respectively. Application of 37,74 and $110 \mathrm{~kg} \mathrm{ha}^{-1}$ urea led to 4, 5 and $12 \%$ increase in 1000-seed weight and 9, 19 and $27 \%$ increase in seed yield compared to control, respectively. Application of 14,27 and $41 \mathrm{~kg} \mathrm{ha}^{-1}$ nano fertilizer led to 8 , 14 and $20 \%$ increase in 1000-seed weight and 31, 44 and $98 \%$ increase in seed yield compared to control, respectively.
In relation to interaction between stress, urea and nano fertilizer on 1000-seed weight, it was found that at normal and stress condition the highest mean of 1000-seed weight ( 46.5 and $44.17 \mathrm{~g}$, respectively) were obtained by $110 \mathrm{~kg} \mathrm{ha}^{-1}$ urea and $41 \mathrm{~kg} \mathrm{ha}^{-1}$ nano fertilizer. In relation to interaction between stress, urea and nano fertilizer on seed yield, it was found that at normal and stress condition the highest mean of seed yield (7591 and $4091 \mathrm{~kg} \mathrm{ha}^{-1}$ ) was obtained by $110 \mathrm{~kg}$ $\mathrm{ha}^{-1}$ urea and $41 \mathrm{~kg} \mathrm{ha}^{-1}$ nano fertilizer.

\subsection{Biological yield and harvest index}

Biological yield and harvest index affected by stress, urea and nano fertilizer at $1 \%$ statistically level. According to mean comparisons, drought stress led to 31 and $29 \%$ reduction in biological yield and harvest index compared to normal irrigation, respectively. Application of 37, 74 and $110 \mathrm{~kg} \mathrm{ha}^{-1}$ urea led to 8,11 and $14 \%$ increase in biological yield and application of 74 and $110 \mathrm{~kg} \mathrm{ha}^{-1}$ urea led to 11 and $18 \%$ increase of harvest index compared to control, respectively. Application of 14,27 and $41 \mathrm{~kg} \mathrm{ha}^{-1}$ nano fertilizer led to 20, 40 and $66 \%$ increase in biological yield and 11,5 and $28 \%$ increase in harvest index compared to control, respectively.

In relation to interaction between stress, urea and nano fertilizer on biological yield, it was found that at normal and stress condition the highest mean of biological yield (27000 
and $15470 \mathrm{~kg} \mathrm{ha}^{-1}$ ) were obtained by $110 \mathrm{~kg} \mathrm{ha}^{-1}$ urea and 41 $\mathrm{kg} \mathrm{ha}{ }^{-1}$ nano fertilizer. In relation to interaction between stress, urea and nano fertilizer on harvest index, it was found that at normal and stress condition the highest mean of harvest index (28\%) were obtained by $110 \mathrm{~kg} \mathrm{ha}^{-1}$ urea and $41 \mathrm{~kg} \mathrm{ha}^{-1}$ nano fertilizer.

Table 3. Means comparison between interaction of treatments on studied traits. (continuing...)

Tabela 3. Comparação entre as interações das características agronômicas avaliadas. (continuação...)

\begin{tabular}{|c|c|c|c|c|c|c|c|c|c|c|c|c|}
\hline \multirow[b]{2}{*}{ Normal } & \multirow{2}{*}{$\begin{array}{c}\begin{array}{c}\text { Urea } \\
(\mathrm{kg} / \mathrm{ha})\end{array} \\
0\end{array}$} & \multirow{2}{*}{$\begin{array}{c}\begin{array}{c}\text { Nano } \\
(\mathrm{kg} / \mathrm{ha})\end{array} \\
0\end{array}$} & \multicolumn{2}{|c|}{ Carotenoid } & \multicolumn{2}{|c|}{$\begin{array}{c}\text { 1000seed } \\
\text { weight }\end{array}$} & \multicolumn{2}{|c|}{ Biological yield } & \multicolumn{2}{|c|}{ Seed yield } & \multicolumn{2}{|c|}{ Harvest index } \\
\hline & & & 0.73 & 0 & 34.83 & $\mathrm{n}$ & 11830 & no & 1833 & $\mathrm{~m}$ & 0.15 & $\mathrm{p}$ \\
\hline & & 14 & 1.33 & $\mathrm{i}$ & 38.83 & $\mathrm{j}$ & 15670 & $\mathrm{j}$ & 4575 & $\mathrm{f}$ & 0.27 & c \\
\hline & & 27 & 1.45 & $\mathrm{~h}$ & 41.33 & fg & 19000 & $\mathrm{e}$ & 5032 & de & 0.25 & de \\
\hline & & 41 & 1.73 & efg & 43.67 & c & 23000 & c & 5883 & $\mathrm{c}$ & 0.24 & e \\
\hline & 37 & 0 & 1.07 & $\operatorname{lm}$ & 36.83 & 1 & 12400 & $\mathrm{n}$ & 3550 & i & 0.25 & i \\
\hline & & 14 & 1.25 & ijk & 40.17 & hi & 18170 & ef & 4483 & $\mathrm{f}$ & 0.23 & $\mathrm{~h}$ \\
\hline & & 27 & 1.65 & $\mathrm{~g}$ & 42.17 & de & 20830 & $\mathrm{~d}$ & 4767 & $\mathrm{f}$ & 0.21 & $\mathrm{j}$ \\
\hline & & 41 & 1.88 & $\mathrm{bc}$ & 44.5 & $\mathrm{~b}$ & 24170 & $\mathrm{~b}$ & 6050 & $\mathrm{c}$ & 0.24 & de \\
\hline & 74 & 0 & 0.92 & $\mathrm{n}$ & 37.83 & $\mathrm{k}$ & 14500 & $\mathrm{k}$ & 4383 & $\mathrm{f}$ & 0.29 & $\mathrm{~b}$ \\
\hline & & 14 & 1.28 & ij & 41.17 & fg & 18000 & $\mathrm{fg}$ & 4608 & $\mathrm{f}$ & 0.24 & $\mathrm{f}$ \\
\hline & & 27 & 1.48 & $\mathrm{~h}$ & 42.5 & $\mathrm{~d}$ & 21000 & $\mathrm{~d}$ & 5008 & de & 0.22 & $\mathrm{gh}$ \\
\hline & & 41 & 1.70 & fg & 44.5 & $\mathrm{~b}$ & 25000 & b & 6667 & $\mathrm{~b}$ & 0.25 & de \\
\hline & 110 & 0 & 1.78 & cdef & 41.5 & efg & 17170 & gh & 4583 & $\mathrm{f}$ & 0.25 & e \\
\hline & & 14 & 1.85 & bcd & 43.5 & $\mathrm{c}$ & 16630 & hi & 4767 & ef & 0.27 & $\mathrm{~cd}$ \\
\hline & & 27 & 1.95 & $\mathrm{~b}$ & 44.5 & b & 21170 & d & 5083 & $\mathrm{~d}$ & 0.23 & $\mathrm{fg}$ \\
\hline & & 41 & 2.25 & a & 46.5 & a & 27000 & a & 7592 & $\mathrm{a}$ & 0.29 & $\mathrm{a}$ \\
\hline \multirow[t]{16}{*}{ stress } & 0 & 0 & 0.65 & o & 32.17 & 0 & 9167 & q & 917 & o & 0.10 & $\mathrm{~s}$ \\
\hline & $\sigma$ & 14 & 1.15 & $\mathrm{kl}$ & 35.67 & $\mathrm{~m}$ & 11330 & op & 2067 & $\mathrm{kl}$ & 0.17 & $\mathrm{n}$ \\
\hline & & 27 & 1.22 & $\mathrm{jk}$ & 37.5 & $\mathrm{kl}$ & 13330 & $\operatorname{lm}$ & 2411 & $\mathrm{j}$ & 0.17 & $\operatorname{lm}$ \\
\hline & & 41 & 1.47 & $\mathrm{~h}$ & 40.83 & $\mathrm{gh}$ & 15500 & $\mathrm{j}$ & 3092 & hi & 0.19 & $\mathrm{kl}$ \\
\hline & 37 & 0 & 1.03 & $\mathrm{~m}$ & 34.17 & $\mathrm{n}$ & 9500 & q & 1300 & $\mathrm{n}$ & 0.12 & $\mathrm{r}$ \\
\hline & & 14 & 1.17 & $\mathrm{kl}$ & 36.83 & 1 & 13830 & $\mathrm{kl}$ & 1958 & $\mathrm{~lm}$ & 0.13 & $q$ \\
\hline & & 27 & 1.53 & $\mathrm{~h}$ & 39.83 & $\mathrm{i}$ & 13830 & $\mathrm{kl}$ & 2267 & $\mathrm{k}$ & 0.15 & p \\
\hline & & 41 & 1.68 & fg & 41.5 & efg & 16170 & ij & 3183 & $\mathrm{~h}$ & 0.19 & $\mathrm{k}$ \\
\hline & 74 & 0 & 0.83 & $\mathrm{n}$ & 34.5 & $n$ & 10670 & p & 1808 & $\mathrm{~lm}$ & 0.17 & $\mathrm{mn}$ \\
\hline & & 14 & 1.22 & $\mathrm{jk}$ & 37.83 & $\mathrm{k}$ & 12330 & $\mathrm{n}$ & 2071 & $\mathrm{kl}$ & 0.16 & 0 \\
\hline & & 27 & 1.28 & ij & 39.83 & $\mathrm{i}$ & 13920 & $\mathrm{kl}$ & 2383 & $\mathrm{j}$ & 0.16 & o \\
\hline & & 41 & 1.50 & $\mathrm{~h}$ & 41.83 & def & 16000 & ij & 3808 & $\mathrm{~g}$ & 0.22 & $\mathrm{i}$ \\
\hline & 110 & 0 & 1.68 & fg & 37.83 & $\mathrm{k}$ & 12500 & $\mathrm{mn}$ & 2042 & $\mathrm{kl}$ & 0.15 & p \\
\hline & & 14 & 1.75 & defg & 40.17 & hi & 11720 & no & 2179 & $\mathrm{k}$ & 0.18 & $\mathrm{mn}$ \\
\hline & & 27 & 1.82 & cde & 42.17 & de & 13830 & $\mathrm{kl}$ & 2458 & $\mathrm{j}$ & 0.17 & $\mathrm{n}$ \\
\hline & & 41 & 1.87 & $\mathrm{bc}$ & 44.17 & $\mathrm{bc}$ & 15470 & $\mathrm{j}$ & 4092 & $\mathrm{f}$ & 0.29 & $\mathrm{a}$ \\
\hline
\end{tabular}

\section{CONCLUSIONS}

This study was performed to evaluation of irrigation interaction with nitrogen fertilizer as urea and nano chelated nitrogen, according to results found that all traits were affected by drought stress and application of nitrogen led to reduction of negative effects of stress on yield traits. Also it was founded that of Nano Chelated nitrogen is best fertilizer for urea substitution in wheat cultivation, due to significant yield increase in lesser doses.

\section{REFERENCES}

ABID, M.; HAKEEM, A.; SHAO, Y.; LIU, Y.; ZAHOOR, R.; FAN, Y.; SUYU, J.; ATA-UL-KARIM, S. T.; TIAN, Z.; JIANG, D.; SNIDER, J. L. Seed osmo-priming invokes stress memory against post-germinative drought stress in wheat (Triticum aestivum L.). Environmental and Experimental Botany, Elmsford, v. 145, p. 12-20, jan. 2018 . DOI: https://doi.org/10.1016/j.envexpbot.2017.10.002

ALI, S.; XU, Y.; JIA, Q.; AHMAD, I.; WEI, T.; REN, X.; ZHANG, P.; DIN, R.; CAI, T.; JIA, Z. Cultivation techniques combined with deficit irrigation improves winter wheat photosynthetic characteristics, dry matter translocation and water use efficiency under simulated rainfall conditions. Agricultural Water Management, Amsterdam, v. 201, p. 207-218, mar. 2018. DOI: https://doi.org/10.1016/j.agwat.2018.01.017

ALLAHVERDIYEV, T. I.; TALAI, J. M.; HUSEYNOVA, I. M.; ALIYEV, J. A. Effect of drought stress on some physiological parameters, yield, yield components of durum (Triticum durum desf.) and bread (Triticum aestivum L.) wheat genotypes. Ekin Journal of Crop Breeding and Genetics, Ancara, v. 1, n. 1, p. 50-62.

ANJUM, S. A.; XIE, X. Y.; WANG, L. C.; SALEEM, M. F.; MAN, C.; LEI, W. Morphological, physiological and biochemical responses of plants to drought stress. African Journal of Agricultural Research, Nairobi, v. 6, n. 9, p. 2026-2032, 2011.

ARJENAKI, F. G.; JABBARI, R.; MORSHEDI, A. Evaluation of drought stress on relative water content, chlorophyll content and mineral elements of wheat (Triticum aestivum L.) varieties. International Journal of Agriculture and Crop Sciences, v. 4, n. 11, p. 726729, 2012

BELTRANO, J.; MARTA, G. R. Improved tolerance of wheat plants (Triticum aestivum L.) to drought stress and re-watering by therbuscular mycorrhizal fungus Glomusclaroideum: Effect on growth and cell membrane stability. Brazilian Journal of Plant Physiology, Campinas, v. 20, n. 1, p. 29-37, 2008. DOI: http://dx.doi.org/10.1590/S1677-04202008000100004

DUBOIS, M.; GILlES, K. A.; HAMILTON, J. K.; REBERS, P. T.; SMITH, F. Colorimetric method for determination of sugars and related substances. Analytical chemistry, Washington, v. 28, n. 3, p. 350356, 1956. DOI: https://dx.doi.org/10.1021/ac60111a017

FAROOQ, M.; HUSSAIN, M.; SIDDIQUE, K. H. Drought stress in wheat during flowering and grain-filling periods. 
Critical Reviews in Plant Sciences, v. 33, n. 4, p. 331349, 2014.

DOI https://doi.org/10.1080/07352689.2014.875291

KEYVAN, S., 2010. The effects of drought stress on yield, relative water content, proline, soluble carbohydrates and chlorophyll of bread wheat cultivars. Journal of Animal and Plant Sciences, Nairobi, v. 8, n. 3, p. 1051-1060, 2010.

LESSANI H.; MOJTAHEDI M. 2002. Introduction to plant physiology (Translation). 6. ed. Iran: Tehran University press, $2002.726 \mathrm{p}$.

LEVITT, J. Stress terminology. In: Turner, N. C.; Kramer P. J. Adaptation of plants to water and high temperature stress. New York: Wiley, 1980. p. 439-473.

LIU, E. K.; MEI, X. R.; YAN, C. R.; GONG, D. Z.; ZHANG, Y. Q. Effects of water stress on photosynthetic characteristics, dry matter translocation and WUE in two winter wheat genotypes. Agricultural Water Management, Amsterdam, v. 167, p. 75-85, 2016. DOI: https://doi.org/10.1016/j.agwat.2015.12.026

IANCULOV, I.; PALICICA, R.; BUTNARIU, M.; DUMBRAVĂ, D.; GERGEN, I. Obținerea în stare cristalină a clorofilei din cetină de brad (Abies alba) şi de pin (Pinus sylvestris), Revista de Chimie, v. 56, n. 4, p. 441-443, 2005.

MENSAH J. K.; OBADONI, B. O.; EROUTOR P. G.; ONOME-IRIEGUNA, F. 2006. Simulated flooding and drought effects on germination, growth and yield parameters of sesame (Seasamum indicum L.). African Journal of Biotechnology, Nairobi, v. 5, n. 13, p. 12491253, 2006.
NADERI, M.; DANESH SHAHRAKI, A. A.; NADERI, R. Application of nanotechnology in the optimization of formulation of chemical fertilizers. Iranian Journal of Nanotechnology, v. 12, p. 16-23, 2011.

NAZARAN, M. H. Chelate compounds. U. S. Patent 8,288,587, 2012.

SCOTT, N.; CHEN, H. 2003. Nanoscale science and engineering for agriculture and food systems. A Report Submitted to Cooperative State Research, Education, and Extension Service, the USDA. National.

WANG, L.; PALTA, J. A.; CHEN, W.; CHEN, Y.; DENG, $X$. Nitrogen fertilization improved water-use efficiency of winter wheat through increasing water use during vegetative rather than grain filling. Agricultural Water Management, Amsterdam, v. 197, p. 41-53, 2018. DOI: https://doi.org/10.1016/j.agwat.2017.11.010

WU, Z. Z.; YING, Y. Q.; ZHANG, Y. B.; BI, Y. F.; WANG, A. K.; DU, X. H. Alleviation of drought stress in Phyllostachys edulis by $\mathrm{N}$ and $\mathrm{P}$ application. Scientific reports, London, v. 8 , n. 1, p. 228. DOI: https://doi.org/10.1038/s41598-017-18609-y

XU, W.; CUI, K.; XU, A.; NIE, L.; HUANG, J.; PENG, S. Drought stress condition increases root to shoot ratio via alteration of carbohydrate partitioning and enzymatic activity in rice seedlings. Acta physiologiae plantarum, v. 37, n. 2, p. 9, 2015.

ZAREABYANEH, H.; BAYATVARKESHI, M. Effects of slow-release fertilizers on nitrate leaching, its distribution in soil profile, $\mathrm{N}$-use efficiency, and yield in potato crop. Environmental Earth Sciences, Heidelberg, v. 74, n. 4, p. 3385-3393, 2015. 